\title{
流動電位法による限外ろ過膜の細孔径と表面荷電密度の評価
}

\author{
中村一穂*・平山稚子・新田見 匡・松本幹治
}

横浜国立大学 大学院工学研究院＝240-8501 神奈川県横浜市保土ケ谷区常盤台 79-5

\section{Estimation of Pore Size and Surface Charge Density of Ultrafiltration Membrane by Streaming Potential Measurement}

\author{
Kazuho Nakamura*, Wakako Hirayama, Tadashi Nittami, Kanji Matsumoto \\ Yokohama National University Graduate School of Engineering, Department of Chemical Engineering \\ 79-5, Tokiwadai Hodogaya-ku, Yokohama 240-8501, Japan
}

Electric conductivity $(\lambda)$ dependency of streaming potential (SP) was measured to estimate the pore size and the surface charge density of the commercial ultrafiltration (UF) membranes having different nominal molecular weight cut-off (NMWCO). At the same $\lambda$ value the absolute value of SP decreased with the decrease in NMWCO in the range of $\lambda>1 \times 10^{-2} \mathrm{~S} / \mathrm{m}$. The pore size and surface charge density of UF membrane could be determined by the analysis of $\lambda$ dependence of streaming potential in the range of $\lambda>1 \times 10^{-2} \mathrm{~S} / \mathrm{m}$ applying a mathematical equation of space charge model. In order to obtain the relation between two pore sizes estimated by SP measurement and the actual separation performance of UF membrane, the MWCO of the UF membrane was measured with $0.03 \mathrm{wt} \% \mathrm{PEG}$ solution. The pore size estimated by SP measurement showed a good linear relation with the Stokes diameter of PEG which has the molecular weight corresponding to MWCO of UF membrane tested. These observations mean the pore size estimated by SP measurement is correlated with the separation performance of UF membrane.

Key words : ultrafiltration membrane $/$ streaming potential $/$ molecular weight cut-off $/$ pore size $/$ surface charge density

\section{1. はじめに}

限外ろ過膜は，コロイドや高分子物質を分離対象 物質としており，その分画性能は分画分子量で評価 される場合が多い。限外ろ過膜の分画分子量は，タ ンパク質やポリエチレングリコール (polyethylene glycol : PEG) などの溶解性高分子を用いて膜の分離 性能を測定し, 溶質の分子量と阻止率の関係（分子 量分画曲線）を求め, 阻止率が $90 \%$ となる分子量と して求められている1 ${ }^{1}$. この測定方法は，使用する溶 質の種類 ${ }^{2 \sim 4)}$, 圧力, 物質移動係数 5,6$)$ など多くの測 定条件の影響を受けることが知られており，これら の条件を一定にして測定を行う必要がある。また,

* Corresponding Author

Tel : 045-339-3980 Fax : 045-339-4012

E-mail : k_naka@chemeng.bsk.ynu.ac.jp
実際に溶質のろ過を行う分離結果に基づく測定であ るため，測定に使用した膜は測定に伴う溶質の膜へ の付着・吸着によりその細孔構造が変化することも 予測される．このように分画分子量の測定では多く の因子の影響を受けるにも関わらず統一された測定 方法が無いため, 得られた值が測定者間で異なるこ とが問題となっている. しかしながら, 分画分子量 は, 環境分野に打ける自然由来有機物（Natural organic matter : NOM）分離やバイオプロセスにおけ るタンパク質分離など限外ろ過膜の多くのアプリケ ーションで膜の選定指標として広く用いられており, 限外万過膜の細孔構造と分画分子量の関係の明確化 が求められている。 これまで, 分子サイズに基づく 解析 ${ }^{2)}$, 原子間力顕微鏡による細孔観察との比較 ${ }^{8}$, 細孔径分布との関係9) などが検討されている. 我々 は流動電位法による精密ろ過膜の評価法に関する開 発を行い, 圧力の加圧方法, 電極の種類の影響 ${ }^{10)}$, 
Table 1 Specification of ultrafiltration membrane (Advantec Toyo Co.)

\begin{tabular}{lcc}
\hline Cat.\# & Nominal MW cut-off $[\mathrm{kDa}]$ & Material \\
\hline Q0100 & 10 & Polysulfone \\
P0200 & 20 & Aromatic Polyamide \\
Q0500 & 50 & Polysulfone \\
Q2000 & 200 & Polysulfone \\
\hline
\end{tabular}

流動電位の測定液の電解質濃度（電気伝導度）依存

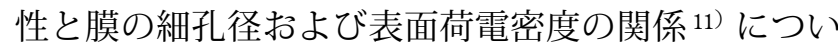
て検討した。 その結果, 流動電位の電気伝導度依存 性は膜細孔径を反映して変化することを明らかにし, それを解析することにより, 膜細孔径扔よび表面荷 電密度が評価できることを明らかにした．この方法 では, 測定には $\mathrm{KCl}$ の溶液を透過させるだけなので 測定に伴う膜の污れの影響がなく，非破壊的に測定 が可能であること，また，全有機炭素計や高速液体 クロマトグラフィーなどによる溶質の分析が不要で あり，自動化も容易である特徴がある．応用として ファウリングした精密ろ過膜の洗浄効果を細孔径の 変化によって評価することが可能であることを明ら かにしている ${ }^{12)}$. 流動電位法を限外ろ過膜の評価に 適応するにあたり, 精密ろ過膜に比べて流動電位の 絶対值が低くなり測定が難しくなると予測されるこ と, また, 流動電位法により求めた細孔径は実際の 膜の分離径に基づくものではないので, 実際の分離 性能との関係を明らかにすることが必要と考えら れる.

本研究では, 流動電位法に基づく限外ろ過膜の細 孔径および表面荷電密度評価法について, 市販の限 外ろ過膜を用いて検討した。また，流動電位法によ り得られた細孔径の妥当性を検討するため, PEGを 用いて使用した膜の分画分子量の測定を行い流動電 位法により求めた細孔径と比較した.

\section{2. 実 験}

\section{1 使用膜}

実験には公称分画分子量 (Nominal molecular weight cut-off : NMWCO） $10 \mathrm{k}, 20 \mathrm{k}, 50 \mathrm{k}$ ，および $200 \mathrm{kDa}$ の 4 種類の市販限外ろ過膜を使用した。使用 した膜の特徴を Table 1 に示す.

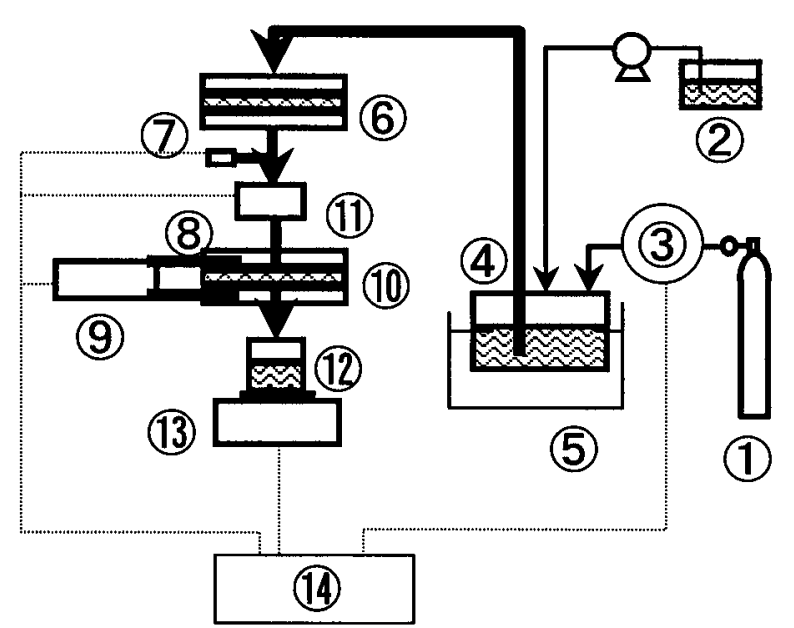

(A)

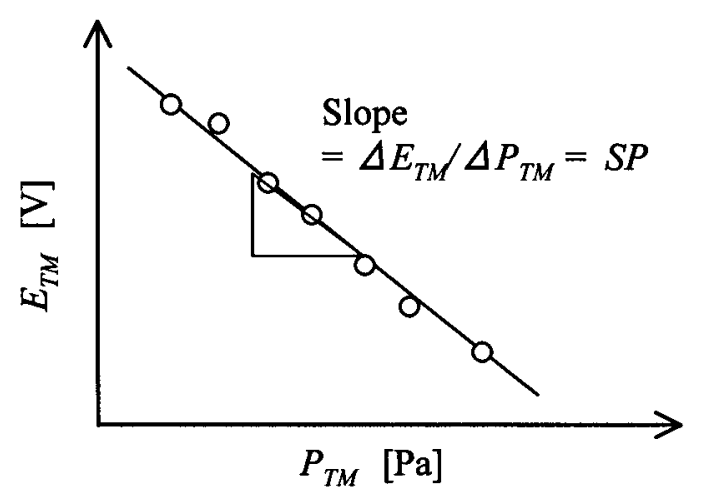

(B)

Fig. 1 (A) Experimental apparatus for streaming potential measurement. 1. $\mathrm{N}_{2}$ gas cylinder, $2 . \mathrm{KCl}$ solution reservoir, 3 . Pressure controller, 4 . Pressure holding tank, 5. Temperature control bath, 6. Prefilter, 7. Pressure transducer, 8. Electrodes, 9. Digital multi meter, 10. Test membrane holder, 11. Electric conductivity flow cell, 12 Filtrate reservoir, 13. Electric balance, 14. Personal computer.

(B) Determination of streaming potential from the relation between $P_{T M}$ and $E_{T M}$.

\section{2 流動電位測定}

流動電位の測定には Fig. 1（A）に示す測定装置を 用いた．測定装置は， $\mathrm{KCl}$ 水溶液貯槽，ペリスタリッ クポンプ, 加圧タンク (Advantec PR2), メンブレン ホルダー (Sartorius $25 \mathrm{~mm}$ ポリカーボネートフィル ターホルダー), 圧力センサ (Kyowa PVL-5KB), デ ジタルマルチメータ (Advantest R6441), 電子天秤 (Shimadzu EB3300SW), 窒素ボンベ, 圧力制御装置, 電気伝導度用フローセル, 電気伝導度計（TOA $\mathrm{CM} 40 \mathrm{G})$, 計測制御用パーソナルコンピュータから 


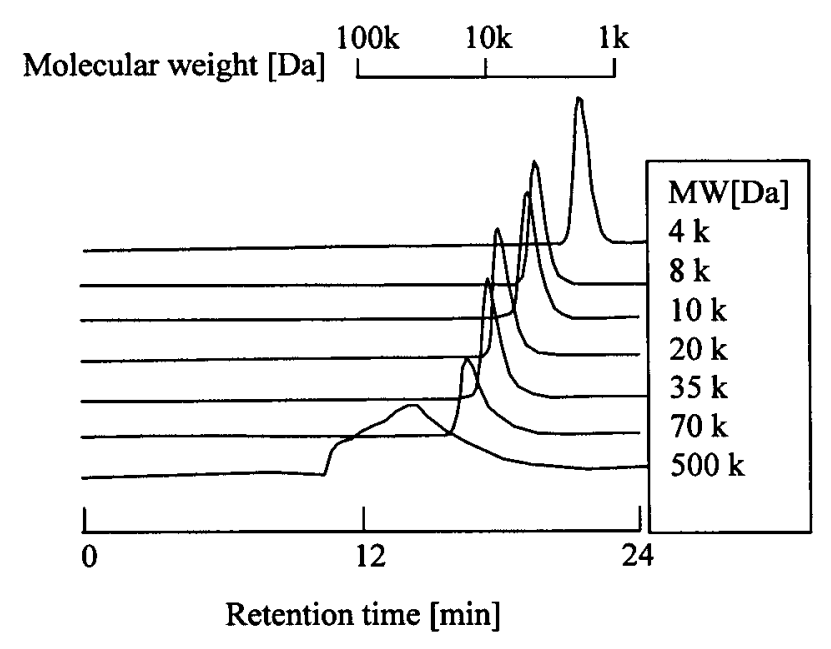

Fig. 2 Gel permeation chromatograms of PEG. (TSK gel

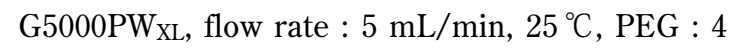
$\mathrm{kDa}$ (Wako), $8 \mathrm{kDa}$ (ICN Biochemical), $10 \mathrm{kDa}$ (Merck), $20 \mathrm{kDa}$ (Wako), $35 \mathrm{kDa}$ (Merck), $70 \mathrm{kDa}$ (Wako), $500 \mathrm{kDa}$ (Wako))

構成されている.膜間電位差測定用の白金黒電極は, 直径 $0.2 \mathrm{~mm}$ の白金線材に白金黒をメッキして作成し た. 作成した電極は, フィルターホルダーの加圧・ 透過の両側にあるフィルター支持体に設置した. メ ンブレンホルダーは恒温槽にて $25 \pm 0.5^{\circ} \mathrm{C} に$ 保った. 測定用電解質として KCl（和光純薬工業 特級）を用 い, 測定液は超純水を用いて大気雾囲気下で調整し, $\mathrm{pH}$ 調整は行わなかった。 測定液の $\mathrm{pH}$ は $5.5 \pm 0.1$ で あった。

実験は以下のような手順で行った。（1）加圧タン クに超純水を入れ，メンブレンホルダーに膜をセッ トした。（2）加圧圧力を，(a）約 15 秒の間に0〜 $0.41 \mathrm{MPa}$ に加圧し，（b）約 45秒間加圧圧力を一定に 保ち，(c) 約 15 秒の間に $0 \mathrm{MPa}$ まで減圧した。 この (a)〜（c）の操作を繰り返した.（3）加圧タンク内 に $\mathrm{KCl}$ 水溶液を添加し, 測定液の電気伝導度を連続 的に上昇させながら（2）の測定を繰り返した。流動 電位 (Streaming Potential : SP) $\Delta E_{T M} / \Delta P_{T M}$ の算出 には, 加圧過程における膜間電位差 $E_{T M}$ と膜間圧力 差 $P_{T M}$ の測定值を Fig. 1 (B) に示すように直線近似 し近似直線の傾きとして求めた。予備実験にて膜を 重ね合わせて測定を行いその影響を検討した結果, SPは膜の重ね合わせの影響を受けなかったことより， SPは膜厚の影響を受けないことを確認した.

\section{3 分画分子量測定}

分画分子量測定用の実験装置は, メンブレンホル ダー, 加圧タンク, ペリスタリックポンプ, 窒素ボ ンベから構成されており, クロスフローろ過方式に
より測定を行った。測定液は, 分子量 $4 \mathrm{kDa}$ (Wako), $8 \mathrm{kDa}$ (ICN Biochemical), $10 \mathrm{kDa}$ (Merck), $20 \mathrm{kDa}$ (Wako), $35 \mathrm{kDa}$ (Merck), 70 $\mathrm{kDa}$ (Wako), $500 \mathrm{kDa}$ (Wako) のポリエチレング リコール（PEG）を所定の割合で混合して調製した $0.03 \mathrm{wt} \% \mathrm{PEG}$ 水溶液を用いた. PEG 水溶液の分子量 分布は, 原液と透過液を凍結乾燥法により濃縮した 後, ゲルろ過クロマトグラフィー（Tosoh TSK gel $\mathrm{G} 5000 \mathrm{PW}$ XL, 流速 $5 \mathrm{~mL} / \mathrm{min}$ ) により求めた. 使用し たPEGのクロマトグラムを Fig. 2 に示す.

\section{SPの解析方法}

毛細管における SP $[\mathrm{V} / \mathrm{Pa}]$ は, 毛細管半径 $r_{p}[\mathrm{~m}]$, 表面荷電密度 $q_{p}\left[\mathrm{C} / \mathrm{m}^{2}\right]$, 電気伝導度 $\lambda[\mathrm{S} / \mathrm{m}]$ の関数 として次式で示される13.

$$
\begin{aligned}
\mathrm{SP}= & \frac{\Delta E_{T M}}{\Delta P_{T M}}=\frac{q_{p}}{\lambda_{\text {eff }} \kappa \mu} \frac{I_{2}\left(\kappa r_{p}\right)}{I_{1}\left(\kappa r_{p}\right)} \\
\kappa^{-1}= & \left(\frac{\varepsilon_{0} \varepsilon_{r} R T}{F^{2} \sum_{i} z_{i} C_{i}}\right)^{1 / 2} \\
\lambda_{\text {eff }}= & \lambda_{\text {avg }}+\frac{q_{p}^{2}}{\mu}\left(1-\frac{I_{0}\left(\kappa r_{p}\right) I_{2}\left(\kappa r_{p}\right)}{I_{1}^{2}\left(\kappa r_{p}\right)}\right) \\
\lambda_{\text {avg }}= & \lambda_{0}\left(1+\frac{q_{p} \kappa^{-1} F}{\varepsilon_{0} \varepsilon_{r} R T}\left(\frac{2}{\kappa r_{p}}-\frac{1}{I_{1}\left(\kappa r_{p}\right)}\right)\right. \\
& \left.\frac{\sum_{i} z_{i}^{3} u_{i} c_{i}}{\sum_{i} z_{i}^{2} u_{i} c_{i}}\right)
\end{aligned}
$$

ここで, $R$ は気体定数 $\left[\mathrm{J} \mathrm{K}^{-1} \mathrm{~mol}^{-1}\right], T$ は絶対温度 $[\mathrm{K}]$, $F$ はファラデー定数 $\left[\mathrm{C} \mathrm{mol}^{-1}\right], z_{i}$ はイオン種 $i$ の価数, $c_{i}$ は毛細管の中心におけるイオン種 $i$ の濃度 $[\mathrm{mol}$ $\left.\mathrm{m}^{-3}\right], u_{i}$ はイオン種 $i$ の移動度 $\left[\mathrm{m}^{2} \mathrm{~mol} \mathrm{~J}^{-1} \mathrm{~s}^{-1}\right], \quad \varepsilon_{0}$ は 真空中の誘電率 $\left[\mathrm{F} \mathrm{m}^{-1}\right], \quad \varepsilon_{r}$ は比誘電率 $[-], \quad \kappa^{-1}$ はデ バイ長 $[\mathrm{m}], \quad \lambda_{0}$ は毛細管の中心における電気伝導度 $\left[\mathrm{S} \mathrm{m}^{-1}\right], \lambda_{\text {avg }}$ は毛細管の平均電気伝導度 $\left[\mathrm{S} \mathrm{m}^{-1}\right]$, $\lambda_{\text {eff }}$ は有効な電気伝導度 $\left[\mathrm{S} \mathrm{m}^{-1}\right], I_{0}, I_{1}, I_{2}$ はそれぞ れ 0 次, 1 次, 2 次の第 1 種修正ベッセル関数を示す. 本研究では, 限外ろ過膜が $\mathrm{KCl}$ の阻止性を示さない こと, また比較的イオン強度の高い条件に対して式 を適応することを想定しているため， $\lambda_{0}$ は測定液の 電気伝導度 $\lambda$ に等しいと仮定した。 SPの計算は，ま ず $r_{p}$ および $q_{p}$ の值を仮定し，ある $\lambda$ に対する $\lambda_{\text {eff }}$ を 


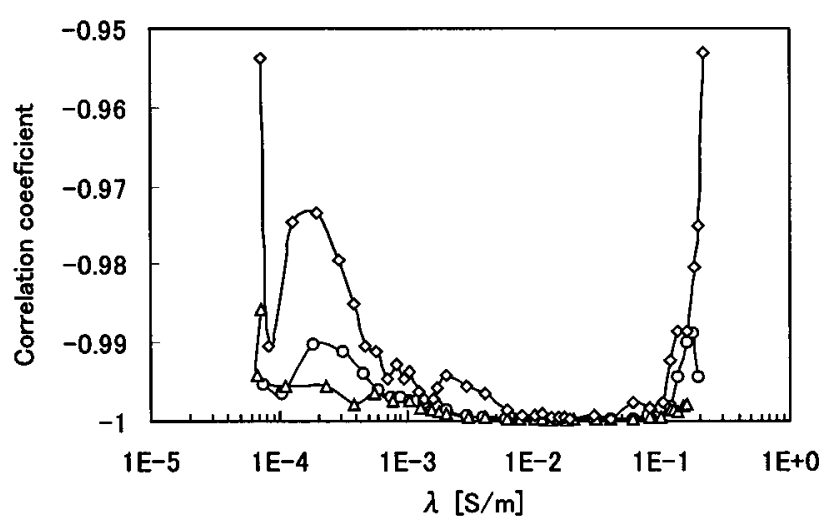

$\triangle:$ Membrane \#1(first time) O: Membrane \#1(second time) $\diamond:$ Membrane \#2

Fig. 3 Correlation coefficient in the linear relation between $P_{T M}$ and $E_{T M}$ measured in UF membranes of NMWCO $50 \mathrm{kDa}$.

式（3），(4)を用いて求め，更にSPを式（1）を用い て求めた。測定した範囲の電気伝導度について同様 の計算を行い電気伝導度とSPの関係を求め, 実測值 に対してカーブフィッティングを行い $r_{p}$ および $q_{p}$ を フィッティングパラメータとして求めた.

\section{4. 結果と考察}

\section{1 限外万過膜の流動電位測定}

$\mathrm{SP}$ の測定精度は測定した $E_{T M}$ と $P_{T M}$ の直線性に依 存するため, $E_{T M}$ と $P_{T M}$ の関係を直線近似する際に 相関係数を求め測定の妥当性を評価した（Fig. 1（B） 参照). Fig. 3 に $E_{T M}$ と $P_{T M}$ の直線関係の相関係数に 及ぼす電気伝導度の影響の例を示す。今回測定した $\mathrm{UF}$ 膜では SP は全て負の值を示したため, 相関係数 が-1に近い值を示すほど直線性が高い関係にある. 相関係数は, 電気伝導度が約 $1 \times 10^{-3} \mathrm{~S} / \mathrm{m}$ 以下と約 $1 \times 10^{-1} \mathrm{~S} / \mathrm{m}$ 以上で上昇する傾向があった．相関係 数が上昇した理由として, 低濃度側では溶解した二 酸化炭素の影響, 高濃度側では $E_{T M}$ の絶対值が低下 するため電位差計の分解能に起因する測定限界が原 因として考えられる. 電気伝導度が, $1 \times 10^{-2} \sim 1 \times$ $10^{-1} \mathrm{~S} / \mathrm{m}$ の範囲では安定してー0.995以下の值が得ら れ，この範囲では精度が高いSPの測定が行えている ことが分かった。

\subsection{SPの電気伝導度依存性とその解析}

SPの電気伝導度依存性の再現性および膜の個体差 の影響を検討した. Fig. 4 に異なる条件の NMWCO
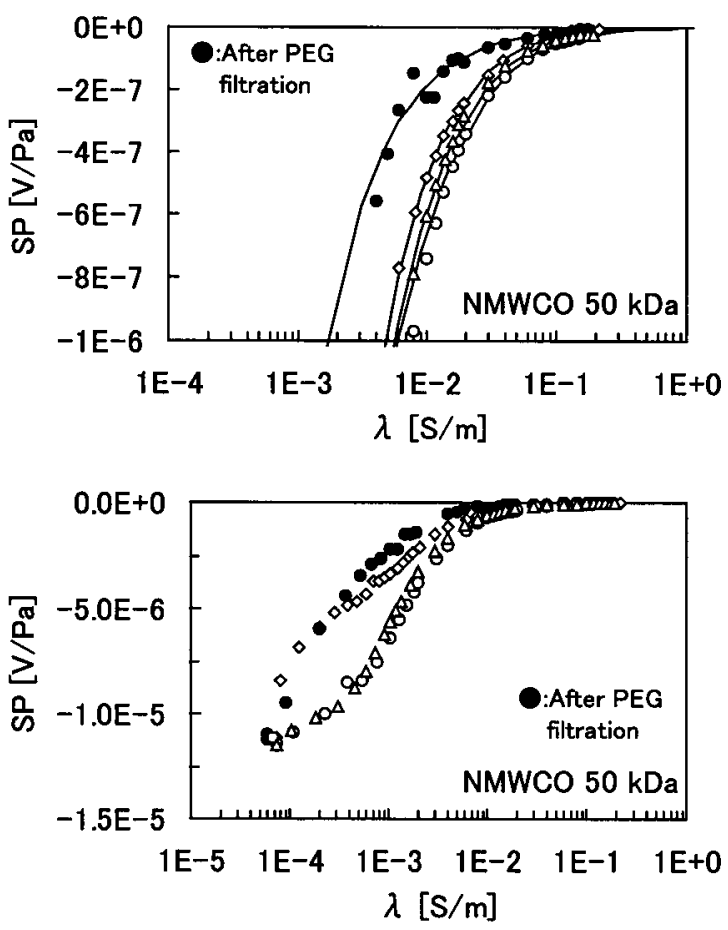

Fig. 4 Influence of membrane condition on the relation between $\lambda$ and SP before and after filtration of PEG by UF membrane (NMWCO $50 \mathrm{kDa}$ ). (The upper panel shows an enlargement of the lower panel.)

$50 \mathrm{kDa}$ の限外ろ過膜を用いて $\mathrm{SP}$ の電気伝導度を測定 した結果を示す. Fig. 4の上図は下図を拡大したもの である. SPは電気伝導度の上昇に伴い上昇し, ゼロ に近づく傾向を示した．同一個体の膜を 2 回測定した 結果, SPの電気伝導度依存性はほぼ等しい曲線を示 し，同一個体の膜に対して本測定方法が高い再現性 を有することが分かる．また，同一ロットの異なる 膜を用いて膜の個体差の影響を検討した結果, SPは, 電気伝導度が約 $1 \times 10^{-2} \mathrm{~S} / \mathrm{m}$ より高い領域では若干 高い值を示したもののほぼ同様の変化を示したが, $1 \times 10^{-2} \mathrm{~S} / \mathrm{m}$ より低い電気伝導度では SPは異なる個 体の膜では異なる変化を示した. NMWCO $10 \mathrm{k}, 20 \mathrm{k}$, および $200 \mathrm{kDa}$ の膜に関しても同様に同一膜におけ る測定再現性と同一ロットで異なる膜間の差異を検 討した結果， $50 \mathrm{kDa}$ の膜の結果とほぼ同様に，同一 膜では高い再現性が得られたが，異なる膜では低電 気伝導度において SPに差が見られた。この低電気伝 導度域における膜個体間のSPの挙動の差異の原因は 明らかではないが, 膜個体間の膜細孔径分布の違い が原因の一つとして考えられる.これらの結果より， 

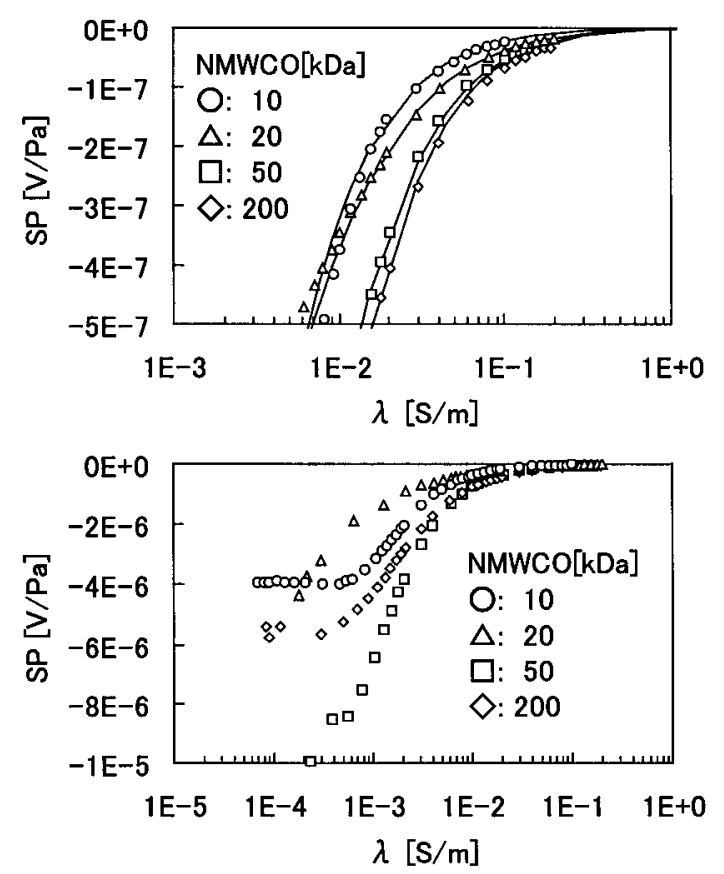

Fig. 5 Effect of NMWCO of UF membranes on the relation between $\lambda$ and SP. (The upper panel shows an enlargement of the lower panel.)

電気伝導度が $1 \times 10^{-2} \mathrm{~S} / \mathrm{m}$ 以上では, 比較的安定し た測定が行うことができることが分かった．Fig. 4に はPEGによる分画分子量測定後の限外万過膜の流動 電位の電気伝導度依存性も示した．測定後の膜は測 定前の膜に比べてその絶対值が低くなる傾向を示し ており，PEGのろ過による膜の細孔構造の変化を反 映したものと考えられる.

Fig. 4 中の実線は式 (1)～（4）による計算線であ る.これらの式により SPの電気伝導度依存性に特有 の S 字型カーブを表現することができるが，SPの電 気伝導度依存性を調べた全濃度域の測定結果に対し て計算結果をフィッティングさせることはできなか った。そこで，SP測定の精度および測定再現性の検 討結果より, 電気伝導度 $1 \times 10^{-2} \mathrm{~S} / \mathrm{m}$ 以上の範囲が 解析範囲として適当であると考え, 表面荷電密度 $q_{p}$ および細孔半径 $r_{p}$ をフィッティングパラメータとし て測定結果へのカーブフィッティングを行い， $q_{p}$ お よび $r_{p}$ を決定した。 以下，この電気伝導度の範囲に 対して解析を行うこととした.

\section{$4.3 \mathrm{SP}$ の電気伝導度依存性に及ぼす NMWCOの 影響}

Fig. 5 にSPの電気伝導度依存性に及ぼす NMWCO の影響を示す．Fig. 5の上図は下図を拡大したもので ある. SPは膜の NMWCO に関わらず電気伝導度の増 加に伴い上昇しゼロに近づく傾向があり，その上昇
Table 2 Fitting parameters and MWCO measured with PEG

\begin{tabular}{|c|c|c|c|c|c|c|}
\hline Nominal & $2 r_{p}$ & Coefficient of & $q_{p} \times$ & Coefficient of & MWCO & Stokes diameter \\
MWCO & {$[\mathrm{nm}]$} & variation of $r_{p}$ & $10^{3}$ & variation of $q_{p}$ & (PEG) & {$[\mathrm{nm}]$} \\
\hline 10 & 12.6 & 33 & -1.43 & 48 & 3.9 & 3.2 \\
\hline 20 & 15.8 & 5 & -1.95 & 61 & 6.8 & 4.4 \\
\hline 50 & 23.4 & 14 & -1.45 & 67 & 10 & 5.6 \\
\hline 200 & 34.6 & 7 & -1.43 & 19 & 41 & 9.6 \\
\hline
\end{tabular}

の様子は NMWCO に依存し， $\lambda<1 \times 10^{-2} \mathrm{~S} / \mathrm{m}$ では NMWCO に対する明確な傾向は見られなかったが, $\lambda>1 \times 10^{-2} \mathrm{~S} / \mathrm{m}$ では SPは NMWCO が小さくなる のに伴いその絶対值が小さくなり, UF膜の分画分子 量すなわち細孔径の差異を反映することが分かった.

$\mathrm{SP}$ の電気伝導度依存性に及ぼす NMWCO の影響を 定量的に評価するため, $\lambda>1 \times 10^{-2} \mathrm{~S} / \mathrm{m}$ の範囲に 対して $r_{p}$ と $q_{p}$ を変化させて式 (1) 〜 (4) により求め た計算曲線をカーブフィッティングし，測定值と良 く適合する $r_{p}$ と $q_{p}$ を求めた. Fig. 5 中の実線は計算結 果を示している．計算結果は測定結果によく一致さ せることができ， $q_{p}$ および $r_{p}$ を求めることができた 同様の測定・解析を複数の異なる個体の膜について 行い，得られた $r_{p}$ と $q_{p}$ を Table 2 に示す。 $r_{p}$ は NMWCO が大きくなるにつれて大きくなり，変動係 数は 5 ３3\%の範囲であった． $r_{p}$ の值は細孔径 25 〜 $800 \mathrm{~nm}$ の精密ろ過膜に対して同様の解析を行い得ら れた值 ${ }^{11 ）}$ と同等かそれ以下の值であり, 限外ろ過膜 の細孔径として矛盾のない範囲の值と考えられる. また， $q_{p}$ はPS膜では $-1.43 \times 10^{-3} \sim-1.45 \times 10^{-3}$ $\mathrm{C} / \mathrm{m}^{2}$, 芳香族ポリアミドでは $-1.95 \times 10^{-3} \mathrm{C} / \mathrm{m}^{2}$ と 評価され変動係数は $19 \sim 67 \%$ であった． $q_{p}$ は，セル ロース混合エステル製精密ろ過膜に対して同様な解 析を行い得られた值 ${ }^{11)}-1.2 \times 10^{-3} \sim-3.0 \times 10^{-3}$ $\mathrm{C} / \mathrm{m}^{2}$ とほぼ同程度の值であった。これらの膜が示す 負荷電の起源は主に細孔表面への陰イオンの吸着で あると予測され，その荷電量を直接評価することは 難しいため, $q_{p}$ の值の妥当性を確認するためには, 表面に解離基を有する膜における測定やSPの $\mathrm{pH}$ 依 存性などのデータを蓄積して総合的に検討していく 必要があると考えられる。

\section{$4.4 r_{p}$ と分画分子量の関係}

$\mathrm{SP}$ の電気伝導度依存性の解析により得られた $r_{p}$ の 值と膜の分離性能との関係について検討するため, 各限外万過膜における PEG の 90\% 阻止率における分 


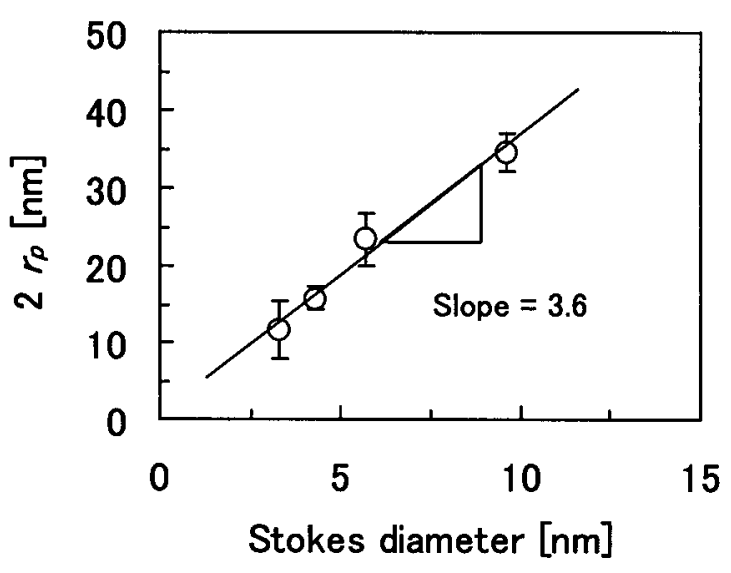

Fig. 6 Relation between $2 r_{p}$ and Stokes diameter of PEG corresponding to MWCO of UF membranes.

画分子量を求めた. Table 2 に測定した分画分子量を 示した．測定した分画分子量は，NMWCOよりも低 い值を示したが，NMWCOが大きくなるにつれて大 きくなる傾向が示された，詹らは，GPCで評価され る PEGの分子量は同一分子サイズの球形タンパク質 分子よりも低く評価される傾向があり，分子量 10 $\mathrm{kDa}$ の球形タンパク質の分子サイズは分子量約 $3 \mathrm{kDa}$ のPEGに相当し, 分子量 $500 \mathrm{kDa}$ の球形タンパク質 の分子サイズは分子量約 $50 \mathrm{kDa}$ の PEGに相当するこ と $^{2)}$ ，また，大矢らは，PEGを用いた GPC測定に基 づく限外ろ過膜の分画分子量の測定では，90\%の阻止 率は NMWCO の約 15～60\%の範囲で得られること ${ }^{5}$ を報告している。本研究で用いた限外ろ過膜のカタ ログからは NMWCO は球形タンパク質の阻止率に基 づく分画特性から求めたものと考えられるので, 本 研究で PEGより求めた分画分子量の傾向はこれら既 往の研究の報告と一致した傾向を示しており，相対 的な指標としては妥当性を有するものと考えられる.

PEGの分子量は分子サイズの指標であるストーク ス直径と関係づけることができる ${ }^{2}$. Fig. 6に，SP法 により求細孔径 $2 r_{p}$ と分画分子量に相当する分子 量のPEGのストークス直径の関係を示す． $2 r_{p}$ とス トークス径は良好な直線関係を示すが，ストークス 直径は $2 r_{p}$ の約 $28 \%$ 程度であることが分かる．ここで 用いたストークス直径は分画分子量の測定に伴う誤 差が含まれるので, $2 r_{p}$ と分画性能の関係は今後さま ざまな膜および物質を用いて同様の解析を行い，デ ータを蓄積し検討する必要がある。しかしながらこ の結果は, SP法から求めた細孔径は限外ろ過膜の分 画性能を直接反映していることを示しており，SP法 により求めた細孔径が UF 膜の分離性能の評価指標と して使用できることを示している。

\section{5. まとめ}

NMWCO の異なる限外ろ過膜を用いて SPの電気伝 導度 $(\lambda)$ 依存性を測定した結果， $\lambda>1 \times 10^{-2}$ $\mathrm{S} / \mathrm{m}$ の範囲では, 同一の電気伝導度における SPの絶 対值は NMWCO が小さくなるにつれて小さくなる傾 向があった. $\lambda>1 \times 10^{-2} \mathrm{~S} / \mathrm{m}$ の範囲の各 UF 膜にお ける SP 測定結果に式 (1) 〜（4）を用いてカーブフ イッティングを行い, 膜の細孔径 $2 r_{p}$ と表面荷電密度 $q_{p}$ を求めた. 求まった細孔径と膜の分画性能の関係 を求めるため, 各膜の PEG $90 \%$ 阻止率を示す分画分 子量を求めた. SPにより求めた細孔径と分画分子量 に相当する分子量の PEGのストークス直径は比例関 係を示し, SP法により求まる細孔径は限外ろ過膜の 分画性能の評価指標として使用できることが分かっ た．また，同時に求まる $q_{p}$ に関してはその妥当性に ついて今後検討を続ける必要があると考えられる.

浄水プロセスや廃水処理プロセスなどで用いられ ている膜ろ過プロセスでは, 膜は常に様々な被分離 物質と接触し污れた状態で使用されるのが普通であ り, 膜の細孔の状態も清浄な膜の状態とは大きく異 なると予測される. SPはろ過中にも測定可能であり, 中空糸精密ろ過膜による河川水の膜ろ過においてフ アウリングに伴うSPの変化が観察されている ${ }^{12)}$ ．予 め $q_{p}$ を求めることができれば, SPの電気伝導度依存 性を測定しなくても，ろ過中に測定したSPの変化を ファウリングに伴うろ過中の細孔径の変化として評 価することができるため, SP法は, 清浄な膜の評価 法に加えて， $q_{p}$ の評価技術と組み合わせることによ りろ過中の細孔径のモニタリング技術としても適応 が可能である考えられる.

\section{文 献}

1）木村尚史，中尾真一，大矢晴彦，仲川 勤：「膜学実 験シリーズ人工膜編」, pp.92-98, 共立出版 (1993)

2) 詹 高白, 中尾真一: 化学工学論文集, 19, 1105-1112 (1993)

3) 柳下 宏, 中根 奎, 高津 晋, 若林勝彦, 吉留 浩 : Membrane, 15, 56-61 (1990)

4) 大矢晴彦, 橋本智佳子, 灰尾明仁, 根岸洋一, 松本幹 治：Membrane, 14, 88-97 (1989)

5) 大矢晴彦, 灰尾明仁, 根岸洋一, 松本幹治: Membrane, 15, 62-71 (1990)

6) 大矢晴彦, 山中博之, 山浦 豊, 灰尾明仁, 根岸洋一, 松本幹治：Membrane, 15, 203-209 (1990)

7) Platt S, Mauramo M, Butylina S, Nyström M : Desalination, 149, 417-422 (2002)

8) Bowen W. Richard, Doneva Teodora A : Surface and Interface Analysis, 29, 544-547 (2000) 
9) Ren J, Li Z, Wong F-S : J. Membr. Sci., 279, 558-569 (2006)

10) 劉 恵元, 中村一穂, 松本幹治：Membrane, 28, 278287 (2003)

11) Nakamura $\mathrm{K}$, Liu $\mathrm{H}$, Matsumoto $\mathrm{K}$ : Membrane, 29, 180187 (2004)

12) 中村一穂，深田尚平，高田綾子，松本幹治：水道協会
雑誌, 75 (2), 2-14 (2006)

13) Newman JS : "Electrochemical System Second Edition", Chap.9, Prentice Hall, New Jersey (1991)

(Received 28 July 2006;

Accepted 13 October 2006)

\section{Nomenclature}

$\begin{array}{lllr}c_{i} & : & \text { Concentration of species ion the center line of pore } & {\left[\mathrm{mol} \mathrm{m}^{-3}\right]} \\ E_{T M} & : & \text { Electric potential difference across membrane } & {[\mathrm{V}]} \\ F & : & \text { Faraday constant } & {\left[\mathrm{C} \mathrm{mol}^{-1}\right]} \\ P_{T M} & : & \text { Pressure difference across membrane } & {[\mathrm{Pa}]} \\ q_{p} & : & \text { Surface charge density } & {\left[\mathrm{C} \mathrm{m}^{-2}\right]} \\ r_{p} & : & \text { Pore radius } & {[\mathrm{m}]} \\ R & : & \text { Ideal gas constant } & {\left[\mathrm{J} \mathrm{mol}^{-1} \mathrm{~K}^{-1}\right]} \\ S P & : & \text { Streaming potential } & {\left[\mathrm{V} \mathrm{Pa}^{-1}\right]} \\ T & : & \text { Absolute temperature } & {\left[\mathrm{K}^{2}\right]} \\ u_{i} & : & \text { Mobility of species } i & {\left[\mathrm{~m}^{2} \mathrm{~mol} \mathrm{~J}^{-1} \mathrm{~s}^{-1}\right]} \\ z_{i} & : & \text { Valence of species } i & {[-]} \\ \varepsilon_{0} & : & \text { Permittivity of free space } & {\left[\mathrm{F} \mathrm{m}^{-1}\right]} \\ \varepsilon_{r} & : & \text { Relative dielectric constant of solution } & {[-]} \\ \kappa^{-1} & : & \text { Debye length } & {\left[\mathrm{m}^{2}\right]} \\ \lambda & : & \text { Electric conductivity of bulk solution } & {\left[\mathrm{S} \mathrm{m}^{-1}\right]} \\ \lambda_{\text {avg }} & : & \text { Average electric conductivity of solution in pore } & {\left[\mathrm{S} \mathrm{m}^{-1}\right]} \\ \lambda_{\text {eff }} & : & \text { Effective electric conductivity of solution in pore } & {\left[\mathrm{S} \mathrm{m}^{-1}\right]} \\ \lambda_{0} & : & \text { Electric conductivity of solution on the center line of pore } & {\left[\mathrm{S} \mathrm{m}^{-1}\right]} \\ \mu & : & \text { Viscosity of solution } & {[\mathrm{Pa} \mathrm{S}]^{2}}\end{array}$

